\title{
Towards a General Development Strategy in The Developing Economy
}

\author{
(With Focus on the Iraqi Economy)
}

\section{Prof.Dr. Hoshiar Marouf}

Department of Business Administration, College of Administration and Economics, Lebanese French University, Erbil, Kurdistan Region, Iraq hoshiarmarouf@hotmail.com

\section{ARTICLE INFO}

\section{Article History:}

Received:24/3/2021

Accepted: 29/4/2021

Published: Spring 2021

\section{Keywords:}

Comprehensive

development, strategic

transformations,

external sector,

structural elements,

perfect technology

package

Doi:

10.25212/Ifu.qzj.6.2.34

\section{ABSTRACT}

The developing economies focused their production and export activities on a few primary materials. In economies that concentrate their exports on crude oil, such as the Iraqi economy, these economies suffer from general structural distortions and are constantly subject to severe fluctuations in the values of their total exports, and then in their other economic indicators, especially trade balance, balance of payments, the state's public budget, as well as the growth rates of investment, national income and employment.

Thus, the relationship between the external sector and the domestic economy has become complicated, and numerous challenges have emerged for the development, especially the overall, processes, which require the identification of the main factors for the strategic transformation of the national economy as a whole. 


\section{Introduction}

The developing economies, including the Iraqi economy, are specialized in producing and exporting one raw material or a very limited number of primary products: extractive and / or agricultural. For Iraq, the concentration in crude oil reaches about $90 \%$ of the total exports as a general average (Ministry of Justice, February 2019). This is reflected in a major distortion of the national economic structure, especially in the external sector indicators: the trade balance and the balance of payments. This sector has grown and become the largest and most important sector in the developing economy.

\section{The research problem}

The overlap of the factors of strategic development with each other on the one hand and with its results and challenges facing this process on the other hand requires an accurate identification of the dimensions of the approved strategy and this can be achieved by answering the following questions:

1. What is the role of institutional development in building and supporting comprehensive strategic development?

2. How can foreign capital trends be shifted in favour of the structural balance and integration in the developing economy?.

3.What is the position of the private sector, individual initiatives, and competitive market systems in the strategic transformations of developing economies?.

4.Do environmental elements have major impacts on targeted strategic shifts?

5.What do the elements of a comprehensive technology transformation include and how will this transformation reflect development strategy?

6.What are the foundations that ensure the stability of exchange rates and support its development effectiveness for the economy? 


\section{Research importance}

As immediately pointed out that the external sector in which crude oil is unique in Iraq is the most dominant sector in the economy and this is what emerges from various indicators such as the rise in the ratio of foreign trade to national income and the ratio of foreign capital to national capital formation and the ratio of acquired technologies to local innovations. Thus, the structural distortions spread to all the concerned economies through several channels, the most important of which are: the balance of payments and the general budgets of the state.

Here, the international economic fluctuations, including some bottlenecks facing advanced capitalist economies, were reflected on the exports of crude oil, and sometimes with worse effects, and the developing countries became hostage to what the developed countries allow in terms of technological acquirements, often concentrated in material aspects (particularly capital equipments) without accompanying knowledge.

On the other hand, the national currencies reflect the continued fluctuations of the main export revenues through the public budgets, which often suffer from the deficit due to the decrease in the mentioned revenues. This causes disruption in investments, an increase in production costs, deterioration in the types of local products, and a decline in the competitiveness of developing economies in the world economy.

Thus it is noted that poverty rates in Iraq are at relatively high levels. The poverty index during the year 2018 according to the survey carried out by the Ministry of Planning to monitor and evaluate poverty in Iraq, which covered all governorates of Iraq, including the governorates of the Kurdistan Region, is about $20 \%$, while the province of Al-Muthanna is still the poorest among the governorates by $52 \%$ (Ministry of Planning and the World Bank 2018))

Here, the importance of this research is highlighted in the strategic confrontation of this phenomenon, which is exacerbated by the environmental conditions in which 
the country is living, in all economic, political, social, cultural, health and security aspects.

\section{Research goals}

The research aims to achieve the following goals:

1. Determine the factors or foundations that can be adopted to build a strategy that is capable of facing the reality of the structural distortion experienced by developing economies, especially since this structural deformation has exacerbated the phenomenon of in the countries concerned.

2. Identifying the challenges facing the long-term strategic development process, due to the complications that the production concentration creates in the external sector and the domestic economy, especially with the response of this economy to the fluctuations to which oil exports are constantly subject.

3. Addressing all environmental, technological and monetary issues related to the approved strategy, with an indication of the appropriate regulations for markets and investment.

\section{Research Hypothesis}

The complexity of comprehensive development challenges and their strategic factors is related to the complexity of the relationship between the external sector and the domestic economy

\section{Research Methodology}

The research is based on the descriptive analytical method, based on the reality of information, publications, studies and theoretical and applied contributions derived from books, scientific journals and electronic information sources (the Internet).

Accordingly, the research deals with the following topics, which constitute the main factors underlying the comprehensive development strategy: 
First: Identifying the challenges facing development strategies.

Second: Neutralizing the role of crude oil in the economic fluctuations.

Third: Providing the appropriate environment for investment and development.

Fourth: transformation of the technological pattern (from a merely capital equipment imports to perfect technology package, knowledge - based acquirement)

Fifth: Government intervention to stabilize the exchange rate of the national currency.

Sixth: Government intervention to support market competition and protect consumers.

First: Identifying the challenges facing development strategies

A number of challenges have emerged facing the development strategies that are expected to be adopted, including: (Ministry of Planning, 2018 and the Central Bank of Iraq)

1. The weakness of institutional management in terms of organization, legislation and efficiency with the spread of various phenomena of financial and administrative corruption. According to the Governance Index of International Transparency, Iraq has become among the top ten most corrupt countries in the world in 2015.

This reality has resulted in the dispersion of activities outside the organized economy, they operate without government control in small units separated spatially and administratively and mostly do not enter into the national accounts.

2. The deterioration of the economic, political, social, cultural and administrative environments in Iraq which have negative impacts on the investment movement in general and on foreign capital in particular thus the general index of Iraq's 
attractiveness for foreign investment was estimated at 3.27 out of 100 degrees, so Iraq was ranked 165 out of a total of 190.

3. Imbalance of structural relations in favour of the extractive oil sector, which contributed in the year 2015 to about $55 \%$ of the gross domestic product, while the share of the manufacturing industrial sector of the same output reached $0.84 \%$ and the share of the agricultural sector $2.2 \%$.

This imbalance was reflected in the trade balance and then on the balance of payments. As the proportion of oil exports rose to $99 \%$ of the total Iraqi exports, the imports varied and their sizes increased until the ratio of foreign trade to the gross domestic product in the year 2016 reached about $61.4 \%$.

On the other hand, the general budget continued to depend mainly on crude oil revenues, which in 2017 accounted for about 98\% of the total revenues of this budget, and this made the Iraqi economy responsive to external shocks resulting from fluctuations in crude oil prices.

4. The exacerbation of the public budget deficit and its financing of external and internal debts have weighed heavily on the economy, society and the state and disrupted investment and development operations and made mainly public revenues relied - as we have already mentioned before - on oil revenues and public expenditures for salaries and rewards. This country has lost the real potential for developing integrated and guaranteed policies, strategies and plans for development.

5. The banking system lags behind the technological and administrative developments in banking operations in the world, and this is reflected in the credit failures of government banks, which were estimated in the year 2015 at $67 \%$.

6. Weak individual initiatives, restricting the role of the private sector, and ignoring the dumping policies practiced by neighboring countries in particular, has led to a decline in production, marketing and financing activities. 
Second: Neutralizing the role of crude oil in local economic fluctuations

As it was previously pointed out that all the fluctuations to which the international crude oil prices are subject, the quantities of demand for this raw material and the dollar exchange rates under which crude oil revenues are assessed are reflected with all restrictions and determinants and regional and international relations on macroeconomic indicators, especially national income, capital formation, investment trends, labour employment, the price movements of goods and resources. Both the balance of payments and the public budget are considered as the most important channels for leakage of the concerned fluctuations, because the ratio of exports to national income in Iraq exceeds the share of national investment (private and public). This reality led to weak national economic control on the growth rates of income and production, if it is possible for internal economic policy to control the level of public spending or the level of private spending, it cannot control exports. As a result, development plans came out with low rates of implementation, which negatively affected the requirements of providing education, health and social care, and the standard of living for citizens in general.

Therefore, serious work must be done to neutralize the role of crude oil in the various channels of disseminating the economic fluctuations generated from this source, especially in the long-term plans for development. This does not mean neglecting the role of crude oil entirely, but rather replacing (a double reserve look) with (almost complete dependence on one primary crop) and by this we mean, considering crude oil as a reserve (as a financial resource and raw material) and thus while the bulk of production is directed towards manufacturing activities it's not considered as the most contributing resource for investment financing. Here, crude oil is combined with the local productive economy on one side, and its export revenues are allocated to fulfill previous financial obligations, on the other.

We affirm here that the issue of self-neutralization requires an integrated strategy based on phased and technical plans that include a gradual transformation during which the productive, marketing and financing environment is provided to raise the 
growth rates of domestic demand for crude oil, which usually responds to the rate of economic growth, especially since the average per capita consumption in Iraq represents about $5 \%$ of the average per capita consumption in advanced economies. What makes this trend more realistic is the degree of industrialization and its diversification in the oil sector in general. Iraq's experience confirms that despite conditions of instability and war, refining capacity, for example, increased from 115,000 barrels per day in 1973 to 835,000 barrels per day in 1993, more than 7.25 times, but development constraints have caused the ratio of actual production capacity to designed productive capacity to decline. (Hoshiar Marouf, 1999.

Iraq established two petrochemical complexes in the 1980s in Basra. The first complex was supposed to operate in 1981 and the second at the end of the decade, but the conditions of the two wars delayed that until the second half of the 1990s.

In any case, Iraq was able, through its oil industries, to produce local alternatives to imported products, from these alternatives, there are different types of oils (for refrigerators, transformers, aluminum rolling, helicopters, aircraft gears ...), hydrocarbon solvents, petroleum fats, medical gasoline, and fire extinguishing foam (Asma Khudair 1993) and (Intesar Razzuqi 1998).).

In addition to the above, refineries and petrochemicals absorb more labour and prepare training centers and publish technical information.

There is no doubt that Iraq possesses an alternative source of crude oil in the balance of payments, which is tourism, especially as there are climatic, topographical, social and cultural conditions that are very different, and that Iraq has countless archaeological and religious sites and centers which can ensure the sustainable tourism development.

The strategy, which was recently announced and promised for a period of five years (2018-2022), aims to diversify the Iraqi economy and reduce dependence on crude oil sales, to follow in the footsteps of the countries that preceded it in adopting economic reform programs, such as Emirates, Saudi Arabia, Kuwait, Qatar and 
Bahrain. By restructuring the national economy, this strategy seeks to develop economic sectors other than crude oil, such as manufacturing industries, services particularly tourism, and agriculture.

Here it is necessary to pay attention to the fact that service activities, especially tourism and manufacturing industrial activities, differ from oil extraction and export activities in terms of the size of the labour force absorption. when the oil industries do not employ more than (1\%) of The total workforce in the country, other activities are often labour-intensive and more reliable to absorb the unemployed people.

Second: Neutralizing the role of crude oil in local economic fluctuations

As it was previously pointed out that all the fluctuations to which the international crude oil prices are subject, the quantities of demand for this raw material and the dollar exchange rates under which crude oil revenues are assessed are reflected with all restrictions and determinants and regional and international relations on macroeconomic indicators, especially national income, capital formation, investment trends, labour employment, the price movements of goods and resources. Both the balance of payments and the public budget are considered as the most important channels for leakage of the concerned fluctuations, because the ratio of exports to national income in Iraq exceeds the share of national investment (private and public). This reality led to weak national economic control on the growth rates of income and production, if it is possible for internal economic policy to control the level of public spending or the level of private spending, it cannot control exports. As a result, development plans came out with low rates of implementation, which negatively affected the requirements of providing education, health and social care, and the standard of living for citizens in general.

Therefore, serious work must be done to neutralize the role of crude oil in the various channels of disseminating the economic fluctuations generated from this source, especially in the long-term plans for development. This does not mean neglecting the role of crude oil entirely, but rather replacing (a double reserve look) 
with (almost complete dependence on one primary crop) and by this we mean, considering crude oil as a reserve (as a financial resource and raw material) and thus while the bulk of production is directed towards manufacturing activities it's not considered as the most contributing resource for investment financing. Here, crude oil is combined with the local productive economy on one side, and its export revenues are allocated to fulfill previous financial obligations, on the other.

We affirm here that the issue of self-neutralization requires an integrated strategy based on phased and technical plans that include a gradual transformation during which the productive, marketing and financing environment is provided to raise the growth rates of domestic demand for crude oil, which usually responds to the rate of economic growth, especially since the average per capita consumption in Iraq represents about $5 \%$ of the average per capita consumption in advanced economies. What makes this trend more realistic is the degree of industrialization and its diversification in the oil sector in general. Iraq's experience confirms that despite conditions of instability and war, refining capacity, for example, increased from 115,000 barrels per day in 1973 to 835,000 barrels per day in 1993, more than 7.25 times, but development constraints have caused the ratio of actual production capacity to designed productive capacity to decline. (Hoshiar Marouf, 1999):

Iraq established two petrochemical complexes in the 1980s in Basra. The first complex was supposed to operate in 1981 and the second at the end of the decade, but the conditions of the two wars delayed that until the second half of the 1990s.

In any case, Iraq was able, through its oil industries, to produce local alternatives to imported products, from these alternatives, there are different types of oils (for refrigerators, transformers, aluminum rolling, helicopters, aircraft gears ...), hydrocarbon solvents, petroleum fats, medical gasoline, and fire extinguishing foam (Asma Khudair 1993) and (Intesar Razzuqi 1998).)

In addition to the above, refineries and petrochemicals absorb more labour and prepare training centers and publish technical information. 
There is no doubt that Iraq possesses an alternative source of crude oil in the balance of payments, which is tourism, especially as there are climatic, topographical, social and cultural conditions that are very different, and that Iraq has countless archaeological and religious sites and centers which can ensure the sustainable tourism development.

The strategy, which was recently announced and promised for a period of five years (2018-2022), aims to diversify the Iraqi economy and reduce dependence on crude oil sales, to follow in the footsteps of the countries that preceded it in adopting economic reform programs, such as Emirates, Saudi Arabia, Kuwait, Qatar and Bahrain. By restructuring the national economy, this strategy seeks to develop economic sectors other than crude oil, such as manufacturing industries, services particularly tourism, and agriculture.

Here it is necessary to pay attention to the fact that service activities, especially tourism and manufacturing industrial activities, differ from oil extraction and export activities in terms of the size of the labour forse absorption. when the oil industries do not employ more than (1\%) of The total workforce in the country, other activities are often labour-intensive and more reliable to absorb the unemployed people.

In any case, it is necessary to link crude oil exports to several indicators, the most important of which are:

1.The change rate of the international obligations.

2. Change of the poverty rate.

3.The rate of global price change.

4.The change rate of the extraction unit.

5. Rate of the reserve change.

-The UN Secretary General said (Kofi Annan, 1998, 34): 
The decrease in the relative importance of raw materials in international trade has led to the increased marginalization of countries specialized in the export of these materials . Consequently, the position of these countries has continued to deteriorate ... Accordingly, he made several proposals previously addressed by UNCTAD, the most important of which is the diversification of basic commodities through the development of small and medium projects and to promote non-traditional exports, especially electronic.

The experiences of the emerging Asian countries have shown that shifting their concern towards promoting exports of manufactured goods and diversifying their local production have led to an increase in the average per capita national consumption by about (6.8\%) during the period 1980-1996. Note that the ratio of investment to GDP increased from (32\%) in 1980 to (39\%) in 1996. On the other hand, in the countries of the Middle East and North Africa, the average growth rate per capita of national consumption was $(0.1 \%)$, meanwhile the ratio of investment to GDP increased from (21\%) in 1980 to (25\%) in 1996 (UNDP1998).

It seems that a serious trend in this way has emerged in the Gulf countries (ESCWA 1994 and the Arab Chambers of Commerce, Adnan Noureddine Bseo 1997) with a view to make structural transformations in favour of export diversification and creation a local and regional production base. Major expansion is expected in the petrochemical, iron and aluminum industries.

It is expected that the contribution of oil to Saudi revenues will decrease from about $81 \%$ (as an annual average during the years 1969-2015) to about $31 \%$ in the year 2030 (Aswaq 2016).

The contribution rate of the oil sector to GDP decreased from $39.1 \%$ in 2012 to $19.3 \%$ in 2016, and the relative importance of oil exports to total merchandise exports decreased from 55.8\% in 2012 to 31\% in 2016. (Economic Statement, September 14 September 2018) 
With regard to Iraq: the oil sector is still the dominant sector in the gross domestic product, as its percentage increased from $26.51 \%$ in 2010 to $55 \%$ in 2015 as a result of the faltering economic policy required to diversify the economy. While the share of the agricultural sector in generating GDP has decreased from 17.4\% in 2010 to $02.2 \%$ in 2015 , and the contribution of the manufacturing sector decreased from $1.2 \%$ in 2010 to $0.84 \%$ in 2015

To address this deterioration, the 2018-2022 development plan identified four basic principles: (Ministry of Planning and the World Bank, 2018)

(1) Governance and its related constituents.

(2) The private sector, a fundamental pillar for the promotion and development, and a transformer of economic diversification policies.

(3) A road map for post-crisis development.

(4) Poverty alleviation in all governorates.

Thus, the productive sectoral transformation within a comprehensive and profound structural distortion, the lack of integration of economic policies, and the exacerbation of administrative obstacles, all of these - as well as the unfavorable military conditions in Iraq - did not give sufficient scope to achieve the desired transformation.

Third: Providing the appropriate environment for investment and development

The environment is defined here as the set of vital elements (water, air, and soil) and other economic and non-economic material and human resources that affect or are positively or negatively affected by all natural and unnatural activities that are achieved in a specific time and place.

Accordingly, the environment includes all economic, social, political, natural, cultural, health ... legislative, and institutional dimensions ... And here in case of 
incompatibility with the capital investment movements and economic and human development trends, many difficulties may be resulted( from this incompatibility).

The importance of this relationship between the environment on the one hand and investment and development on the other hand is highlighted when we visualize the following:

(A) The failure of advanced technologies that are capital -intensive in areas where skilled technical manpower is not available.

(B) The developing country needs foreign investment when its non-primary sectors suffer from local isolation due to its backwardness and isolation internationally, especially as these investments create opportunities to establish new projects and participate in local investments, so the opportunities for developing national activities increase technologically and administratively, and foreign investments help to share local products in international markets and this boosts non-primary exports.

C) Operating industrial units in a developing country in accordance with their design capabilities dependent on an advanced economic environment and in light of the restrictions or limitations of the prevailing international relations.

(D) Providing full employment opportunities, raising real incomes, and overcoming the disparity in the distribution of national income in a country that suffers from a heavy burden of foreign debt.

(E) Increased site attraction factors for industrial activities in major urban centers such as the capital of the country and the capitals of the interior regions, at the expense of rural and semi-urban areas and the exacerbation of the phenomenon of environmental pollution.

The concern of the United Nations with the environment led to the emphasis on sustainable development, which was known as: (UNIDO, 1996) 
Patterns of the manufacturing process linking industrial activity with economic and social benefits extending from current generations to future generations in a path that avoids negative effects on the environment and accelerates development rates during time and ensures efficient use of non-renewable resources as it works to conserve these resources and eliminates waste and neglect). years after the United Nations Conference on Human Development in Stockholm which was the first international meeting to place the issue of the environment on the international calendar (JA Miller and J. Cornock, 1997, 6). The United Nations Environment Program (UNDP, 1998), which is based in Nairobi, Kenya, considered promoting the environment for the benefit of the poor as one of its first goals..

With regard to Iraq, there is a clear trend to study investment offers related to the oil industry and other activities, and indeed certain agreements were concluded during the recent period. After the country recovers its previous role in international relations, this trend will grow more and the Iraqi economy will be more open to the outside world. Here it is necessary to work on attracting foreign capital and creating the environment to ensure the stability of working capital at home and to achieve this double goal it is necessary to work on the integration and stability of legislation, institutions and economic policies, all of this in a way that guarantees all shareholders the freedom to transfer, enter and return their capital while providing infrastructure and administrative bodies And information sources that facilitate the settlement of investments and provide the basic requirements for the work and livelihood of contractors and officially licensed workers.

This does not mean that the forms should be edited completely, as some social, cultural and ethical restrictions must be put in place, in addition to abiding by international standards or standards, while avoiding all that causes sabotage of the national economy.

Fourth: The transformation of the technological pattern 
No doubt that all developing countries are working to achieve rapid and comprehensive transformations towards capital-intensive technologies based on modern electronic systems. However, such transformations face many challenges and difficulties, including:

1. Lack of human resources from skilled technical cadres capable of operating, maintaining and developing modern equipments .

2. The inability of developing countries immersed in their international obligations to cover the costs of importing the required technologies.

3. Western institutions or markets are not ready to supply all equipments, materials and information required by developing countries.

4. The absence of a dynamic balance between productive and absorptive capacities, especially if different technologies are imported in their origins, specifications, and efficiencies ...

As a result, the search for rapid and comprehensive transformations in a short period necessarily implies a considerable waste of economic resources (natural, material, financial, and human) and thus the distortion of economic, social and cultural structures is further exacerbated and the level of satisfaction of the basic needs of citizens is deteriorating at a greater rate, and since technological development is the basis for maximizing the productive efficiencies of establishments, resources, and workers, this ensures maximum benefits. This is in addition to supplying markets with the best goods and services. Thus, overcoming poverty and deprivation is largely related to Technological phase.

Accordingly, we propose adopting a long-term strategy to spread the process of technological transformation according to a phased progression:

For this purpose, the country's regions are classified into three groups: (a) advanced. (B) Transitional.And (C) backward. 
And given that the proposed strategy adopts an alternating relationship between a typical labour- intensive and capital - intensive patterns in a phased manner during the diffusion of modern technology from one region to another it is called the Tradeoff Strategy of Technology Diffusion

This strategy includes the following stages:

The first stage: - It includes:

1. Deepening capital - intensive technologies in Group (A) by increasing electronic development and providing semi-skilled work.

2. Reorganization of Group B while expanding the productive capacities of the existing units and organizing the small and medium units in integrated complexes.

3. Infrastructure development in Group C, especially for transportation and coomunications, storage and training.

The second stage: It includes:

1. Resettlement of high-density installations to work with their productive nature, such as manual carpets, towards Group B.

2. Capital intensification in groups $A$ and $B$.

3. Resettlement of facilities to the most profitable and / or less polluted sites.

4. Deepening productive linkages within and between groups A and B.

5. Publishing training centers and institutes in all groups.

6. Raising the rate of spending on research and development in $(A)$ to $(10-12 \%)$ of the total expenses and in (B) to $(8-10 \%)$ and $(C)$ to $(5-8 \%)$.

The third stage:It incudes 
1. Capital intensification in the three groups (A), (B), and (C), according to the production activities.

2. Symbiosis of the two patterns labour-intensive and capital-intensive.

3. Intensifying technological links among the units of the three groups.

4. Universities, colleges, institutes, and technological centers have to establish and develop research, consulting and training centers and obligate economic establishments to increase research and development expenditures to total production and marketing expenditures in all large units and groups of small and medium units Estates to (10-12\%).

5. Building and developing specialized applications according to the production branches.

6. Establishing extensive networks of information in all regions of the country, according to the Intra and Inter systems.

Fifth:. The government intervention to stabilize the exchange rate of the national currency

The Iraqi dinar exchange rate has been subjected to a continuous decline since the mid-1980s, but the fluctuations were severe in 1960s. These fluctuations resulted in an escalation in the prices of imported goods as well as the prices of domestic products dependent on foreign intermediate materials, and this was always reflected in the high cost of living of people with limited and low incomes. In view of the lack of flexibility in the production system, exports stimulated by the deterioration of the dinar exchange rate often included either re-exports of goods, products provided by the assembly industries, or materials that were processed primarily, in addition to crude oil and some of its products. Consequently, the groups most negatively affected by the deterioration of the national currency exchange rate are the groups of the poor and the educated people with limited incomes. 
Here, it is necessary to search for a formula to unify the exchange rates of the dinar in a way that avoids distortions resulting from exaggeration, so that the nominal price approaches the real price (Salem Al-Najafi 1999).

Bella Plaassa emphasized this amendment when he proposed to Tunisia to reduce the dinar exchange rate by $(10 \%)$ while providing incentives or conditions sufficient to boost exports, and that was when the rise or exaggeration of the Tunisian dinar exchange rate by (7\%) led to a loss of European markets in favour of other countries such as Morocco, Portugal and Turkey (Abdel Fattah Al Amous 1997, 39)

Here, it is necessary for the state to interfere in removing cases of collusion or monopoly with the exchange markets, so that the market mechanism works in a framework that guarantees the stability of the exchange rate.

This does not mean that some guiding prices are not approved, for example, the official exchange rate can be reduced in a graphic way for purposes of assessing the inputs and outputs of specific projects. This is done through an adjustment factor based on the ratio of expected receipts from foreign currency to the expected payments from the same currency, i.e.:

If $\mathrm{R}=$ Expected ForeignExchange Receiots

$\mathrm{P}=$ Expected ForeignExchange Payments

F= Formal Exchange Rrate

$E=$ Exchange Rate

$\mathrm{E}=\mathrm{F} \times \frac{R}{P}$

Receipts for visible and invisible exports and payments relate to visible and invisible imports. 
Sixth: Intervention for the purpose of market competition and consumer protection

The Iraqi markets were subject to the local private sector since the beginning of the twentieth century until the year 1964 when nationalization decisions were issued against some commercial, credit and industrial companies. In that period, there was no tangible role for the government to intervene, with the exception of two cases: one - when it imposed escalating fees on light fabrics under the British mandate in order to limit competition for Japanese goods to British goods in Iraqi markets (Muzaffar Hussain Jamil, 1949, 329)

The other was when the government provided basic food commodities according to the approved marketing system during the Second World War. With the exception of these two cases, the local markets adopted the laws of supply and demand and at the same time were subject to external fluctuations due to the dependence of the Iraqi economy and the local and regional (and international conditions such as the Korean War and the tripartite aggression against Egypt) which were constantly fluctuating.

Since the issuance of nationalization decisions in the year 1964 until the mideighties, the government almost completely controlled the Iraqi markets by relying on many means, including:

1- Legislations or procedures restricting the movement of markets.

2- Monopolizing some commercial activities (goods and services).

3- Pricing of various goods and services by the Central Authority for Prices and many government agencies.

4- Supporting national production by providing production requirements at reduced prices.

5- Protecting national production by exempting it from taxes and fees. 
Since the second half of the eighties, import trade was launched without external currency transfer, and since the beginning of the nineties, it has been almost completely permitted for importers to provide goods from various origins and with various means, methods and organizations. And where open inflation prevailed, due to the fluctuation of the supply and, traders competed for the accumulation of their huge stocks (often) to take advantage of the successive and increasing price increases. This situation continued until the price levels of basic commodities and the Iraqi dinar at the end of 1995 reached more than (3000) times the levels reached at the end of 1989 until the Secretary-General of the United Nations in Paris said that Iraq agreed in principle to exchange oil for food and basic needs, as a result of which the local markets collapsed, which led to a sharp drop in all prices, including the exchange rate of the dollar to about $10 \%$. However, this trend was struck by a kind of stagnation and then reflected Quite the price rises again in late 1999. And that this shift came due to the following reasons:

1. Merchants' accumulated stocks depleted with the decline in prices in the first months of the year 1996. Importation was linked to domestic demand rather than long-term storage.

2- The daily accounts are often done in dollars instead of dinars, and this is what traders have avoided the problems related to fluctuations in the exchange rates of the dinar.

3- The market collusion among merchants has clearly increased in all commodity areas. The February 1996 experience with the sharp drop in prices taught them that this collusion was necessary to face the aftershocks that occurred in December of the same year and then in February 1997 with news related to the easing of the international blockade and even near the complete release of this blockade.

\section{Conclusions and recommendations}

From the above we draw the following conclusions 
1. Economic development requires interrelated structural transformations in all its economic, social, political, cultural and health dimensions. The concerned transformations are complicated with the emergence of many economic and administrative challenges in the absence of institutional management and with the existence of conflicting and unstable legislations and thus lack of transparency when dealing with different issues.

2. Fragmentation and dispersion of economic establishments between small units with high production costs dominated by the informal sector, and this has worsened the competitive position of local products in favour of imported products that are usually supported by external dumping policies, especially from neighboring countries.

3. The deterioration of political, economic and social stability has negatively affected the movement of inward foreign investments, because these investments that focus on the production and export of raw materials are looking for safe environments that guarantee them high and stable profitability, but they have in fact been met with political and even military disturbances in addition to the absence of appropriate credit facilities and basic infrastructure and all that with accumulated deficits in the general budget and trade balance that are always threatened by fluctuations in the primary export revenues and, above all, financial and administrative corruption prevails in the government administrations.

As a result, investment risks of the international companies increase in developing countries, especially with regard to manufacturing industries, modern technology, advanced agriculture, tourism and credit activities.

4. Increasing structural distortion in favour of primary activities, especially crude oil, so the role of the agricultural and manufacturing sectors and technologically advanced services have decreased. Moreover the allocations of public expenditures have turned towards salaries and wages instead of investments 
Based on the foregoing, we present some of the recommendations that can enhance the diversification of the developing economy:

1. Integration and stability of legislations, institutions and economic policies at the macro and micro levels, in a way that brings a fundamental shift in the structural relations in favour of compatibility between the two capacities: productive and absorptive through stimulating investment in developing non-traditional activities and diversifying production directed for export purposes.

2. Adopting the self-financing system in all public economic establishments, which places them in a position of responsibility, and it bears the burdens of developing their production capacities and enhances their marketing capabilities inside and outside the country.

3. Establishing centers specialized in research and development (R\&D), while requiring all public, private and mixed establishments to allocate (8-12\%) of their net profits for this purpose. The actual spending will be followed up by the financial supervision authorities.

4. Liberating the movement of foreign capital from all restrictions except those that contradict the applicable laws, and we propose at the outset to stimulate foreign direct investment in the free zones and then push this investment towards opportunities that achieve diversification in non-oil exports..

5. Publishing the specifications or standards adopted by (ISO) through printed brochures, training courses and technical consultations, all of which makes national products able to compete with foreign products inside and outside the country.

\section{References}

1.ESCWA, A Survey of Economic and Social Developments in the ESCWA Region , 1994.

2.Asmaa Khuthier; Analysis of the Structural Developments in the Inadustrial Manufacturing Sector , PHD Dissertation ,the Baghdad University ,Baghdad ,1993, 


\section{QALAAI ZANISTSCIENTIFIC JOURNAL}

A Scientific Quarterly Refereed Journal Issued by Lebanese French University - Erbil, Kurdistan, Iraq

Vol. (6), No (2), Spring 2021

ISSN 2518-6566 (Online) - ISSN 2518-6558 (Print)

2. الأمانة العامة للإتحاد العام لغرف التجارة و الصناعة و الزر اعة للبلاد العربية، أوراق إقتصادية، العدد14،

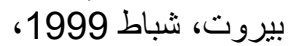

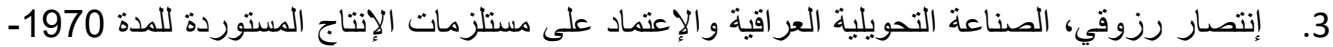

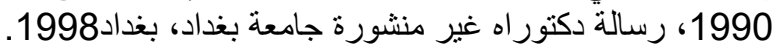

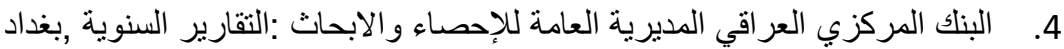

5. البيان الاقتصادي , 14 سبتمبر ايلول , 2018 , (التتويع الاقتصادي يقلص دور النفط في ناتج الامارات

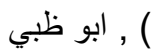

6.

https://alarab.com.uk/

9 عبد الفتاح العموص(1997) : (النماذج التأليفية لصندوق النقد الولي والبنك العالمي , الأسس النظرية والحالات

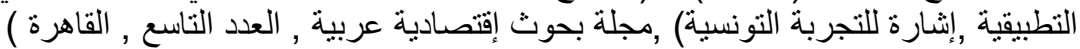

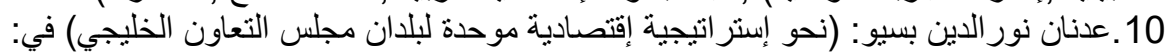

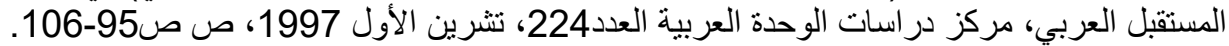

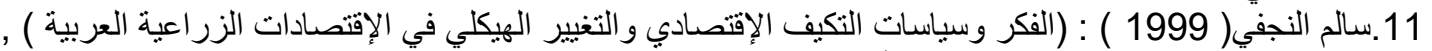

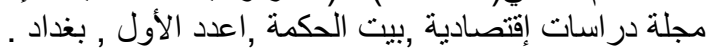

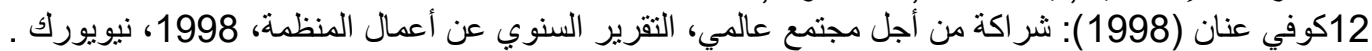

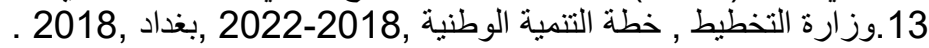
14.وز 13 ارة التخطيط والبنك الدولي(2018): إستر اتيجية التخفيف من الفقر 2018-2022 https://alforatnews.com/modules/news/article.php?storyid=215355

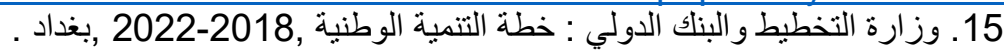

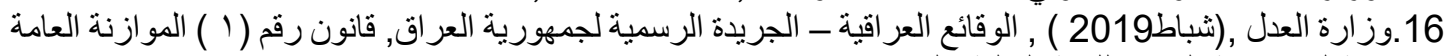

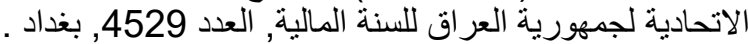

http://www.bayancenter.org/wp-content/uploads/2019/02/4529.pdf

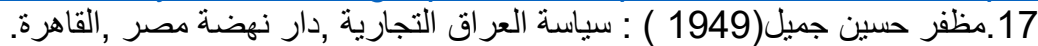
18. ـ هوشيار معروف (1999) : التوافق بين الطاقة الإنتاجية والطاقة الإستيعابية في القطاع الصناعي التحوية التحويلي، في مجلة الإقتصادي، جمعية الإقتصاديين العر اقيين، بغداد. 19-J.A. Miller and J. Cornock: Bridges to sustainability (Bulletin Series No. 101) Yale School of Forestry and Environment, New Haven Connecticut.

20-UNIDO, (1996) Industrial Development Global Report, 1996, OUP, London.

UNDP, (1998): Poverty Report. 


\section{QALAAI ZANISTSCIENTIFIC JOURNAL}

A Scientific Quarterly Refereed Journal Issued by Lebanese French University - Erbil, Kurdistan, Iraq

Vol. (6), No (2), Spring 2021

ISSN 2518-6566 (Online) - ISSN 2518-6558 (Print)

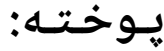

ئابوريهكانى كه له گهشه كردن دانه زورترين گرينگى دهدهنه بهرههم هينان و و ناردنهدهرومى كالايهكى سهرهتايى ياجهند كالايهكى كهمى سهرهتايى جا ئهمه كشت و كالى بى يا كانزايى بى.لهم ولاتانهى كه زور بهى خويان بهستوتهوه به ههناردنه كردنى نهوتى خاو بو دهرهوه وهك ئابورى عيراق ئهم ئابوريانه كهوتونهته زير دياردهى ييكهاتهى شيواو جا ئهم ئابوريانه بهردهوام له بهرزى و نزمى دانه له ييشهوه له بههاى ههناردهكراومكانيان وزوربهى دهرخهرهكانى ترى داهاتى نهتهوايهتى به تايبهتى تهرازوى دراوو تهرازوى بازركانى و بوجهى گشتى وولات و دوايى له بزوتنهوهانى وهبهرهينان و داهاتى نهتهوايهتى وتواناكانى بهرههم هينان وبه كاربوونى هيزى كار .

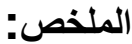

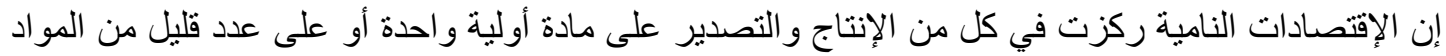

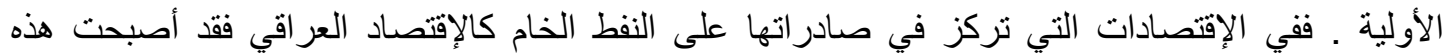

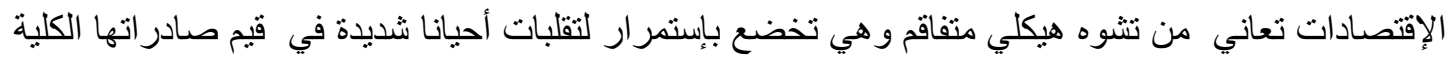

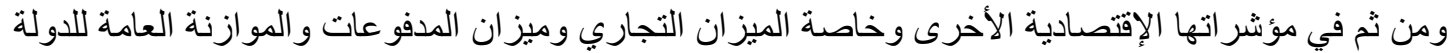
ومن ثم في حركات الإستثمار و الدخل القومي وتثنغيل كل من الطاقات الإنتاجية المتاحة و القوى العاملة العانة .

و هكذا تعقدت العلاقة بين القطاع الخارجي و الإقتصاد المحلي فبرزت تحديات عديدة للعمليات التنموية وخاصة الثاملة مما يتطلب تشخيص عوامل أو أسس التحو لات الإستر اتيجية في الإقتصاد الوطني ككل . 